\title{
Effect Application of Technique Partial Rootzone Drying (PRD) on the Growth, Yield and Quality of Tomatoes
}

\author{
Muhammad Idris ${ }^{1}$, Dermawan Hutagaol ${ }^{1}$, Nurma Ani ${ }^{1}$ \\ ${ }^{1}$ Lecture Departement Agrotechnology of Agriculture Faculty of Al-Azhar University, Medan North Sumatera . \\ Indonesia \\ idris_juki@yahoo.com
}

\begin{abstract}
The research was conducted to evaluate the performance of tomatoes varieties on growth, yield and quality through the application of partial rootzone drying. The study was conducted in green house at the Faculty of Agriculture Universitas Islam Sumatera Utara (UISU) Medan in May 2014 until September 2014. The planting media used were straw compost mixed with top soil enriched withUrea, SP-36 and KCL fertilizer filled into polybeg up to $10 \mathrm{~kg}$ in weight. Observation variables are: the growing, yield and quality of tomato
\end{abstract}

Keywords : efficient use of water; partial rootzone drying; tomatoes

\section{Introduction}

Drought is a servere problem in the 21 st century worldwide. Percentage of areas in the world that suffer from drought since 1970 to 2000 more that doubled Population growth, pollution and climate change are also accelerating the dramatic drop in water supply in coming decades (Steduto at al, 2009). Second world water forum in the Hague in March 2000 has been predicted Indonesia is among countries that will occur water crisis in 2025. The crisis will occur as a result of errors in water management is an inefficient use of water and high levels of water pollution.

Increasing water use efficiency is a major goal for researcher in the face of water scarcity and continuation of high water demand for agriculture.. Partial rootzone drying (PRD) is the strategy of water saving irrigation potential, which in any water supply is only one of part of the irrigated rootzone. PRD can save up to $50 \%$ water and maintain the results as seen in some grape varieties (Loveys, et al, 2000). PRD is a variation of the technique deicit irrigation (DI). Where AT is a strategy is the provision of water in the rootzone of less than full irrigation (FI) which causes a mild water stress. The effect a mild water stress is little on crop yields. PRD can increase efficiency of water and also fruit quality. Beside the quality is better than before, PRD also can be used in different ways, depanding on crops grown, soil and environmental conditions and also methods of irrigation.

Today, tomatoes is one horticultural commodities with high economic value and still requires serious treatment, especially in terms of increasing the results and quality of fruit. The tomato fruit vegetables most favored by everyone, because it feels good, fresh and slightly sour. In addition it has and old tomato and red is source of vitamin $\mathrm{A}$, vitamin $\mathrm{C}$ and a bit of bitamin B. Although the theory of PRD has developed, but still a little know how to respond tomatoes that grow in dry and wet climatic conditions of PRD this technique.

\subsection{Experimental Site}

\section{Research Methodology}

The study was conducted in green house Agriculture Faculty Universitas Islam Sumatera Utara (UISU) Medan at altitude $\pm 30 \mathrm{~m}$ above sea level. The research was conducted from May 2014 to September 2014. 


\subsection{Materials and Equipment}

Materials use in this study were varieties tomato Niki F1, Permata and Mentari. The planting media used were straw compost mixed with top soil enriched with Urea, SP- 36 and KCL fertilizer filled into polybeg up to $10 \mathrm{~kg}$ in weight.

\subsection{Research Method}

This research used a randomized block design factorial consisting of 3 (three) applications and 2 (two) factors, namely:

Factor 1 : varieties of tomatoes which consists of three varieties namely $\mathrm{V} 1=$ variety

Niki F1; V2 = variety permata and V3 = variety mentari

Factor II : interval giving water (1) which consists of five levels ie:

F1 (P1) = irrigation full(field capacity) with the water added everyday.

F2 (P2) = deficit irrigation ( a half field capacity) with the water added optimum everyday.

$\mathrm{F} 3(\mathrm{P} 3)=$ partial rootzone drying at intervals of one day with the water added once (a half field capacity) at intervals of one day (the water added once).

PRD $(0)(\mathrm{P} 4)=$ partial rootzone drying with the intervals of the water added two days.

$\mathrm{PRD} 15(\mathrm{P} 5)=$ partial rootzone drying at intervals of the water added three days.

Number combination $3 \times 5=15$

Number replication $\quad=3$ replication

Total polybeg trial $\quad=45$ polybeg

Distance between polybeg $=15 \mathrm{~cm}$

\subsection{Implementation Research}

The crop maintenance was carried out soil preparation, nursery, planting, fertilization, and plant maintenance (insertion, the added of water, weeding, pruning, pest and disease control) and harvesting.

\subsection{Variables Observation}

Observation that: plant height, number of leaves, total chlorophyll respectively at the age $2-8$ weeks After planting (WAP), Wet Weight canopy, dry weight canopy, Wet Weight Root, dry weight root. and Leaf Area Index respectively at the age 4 weeks After planted (WAP), the amount of flowers, the amount of fruits , weight of fruits and Total Soluble Solution (TSS) respectively at harvest.

\subsection{Data analysis}

If the test results of the study showed significant differences of treatment is attempted, can proceed with the test method honest difference score (DMRT)

\section{Result and Discussion}

\subsection{Result}

Effect of varieties and techniques giving of e water on plant height, number of leaves and chlorophyll tomatoes at the age of 2 to 8 WAP are presented in Figure 1.2 and 3. 
Figure 1 shows that the best results at age 2 WAP obtained at treatment V1 (Variety Niki F1), with plant height of $33.34 \mathrm{~cm}$ followed by V2 (Variety Jewel) with $31.50 \mathrm{~cm}$ plant height and the lowest plant height V3 (varieties Mentari) that is $24.4 \mathrm{~cm}$.

Figure 1 also shows the best results at the age of 4 WAP obtained at treatment V2 (Variety Permata) with plant height of $50.0 \mathrm{~cm}$, followed by V1 (Variety Niki F1) with a plant height of $49.5 \mathrm{~cm}$ and the lowest plant height V3 (varieties Mentari) ie $32.3 \mathrm{~cm}$

Figure 1 also shows the best results at the age of 6 WAP obtained at treatment V1 (Variety Niki F1) with $103.70 \mathrm{~cm}$ plant height, followed by V2 (Variety Permatal) with plant height $101.80 \mathrm{~cm}$ and the lowest plant height V3 (varieties Mentari) ie $61.20 \mathrm{~cm}$

Figure 1 also shows the best results at the age of 8 WAP obtained at treatment V2 (Variety Permata ) with $204.10 \mathrm{~cm}$ plant height, followed by V1 (Variety Niki F1) with plant height $185.80 \mathrm{~cm}$ and the lowest plant height V3 (varieties Mentari) that is $154.10 \mathrm{~cm}$.

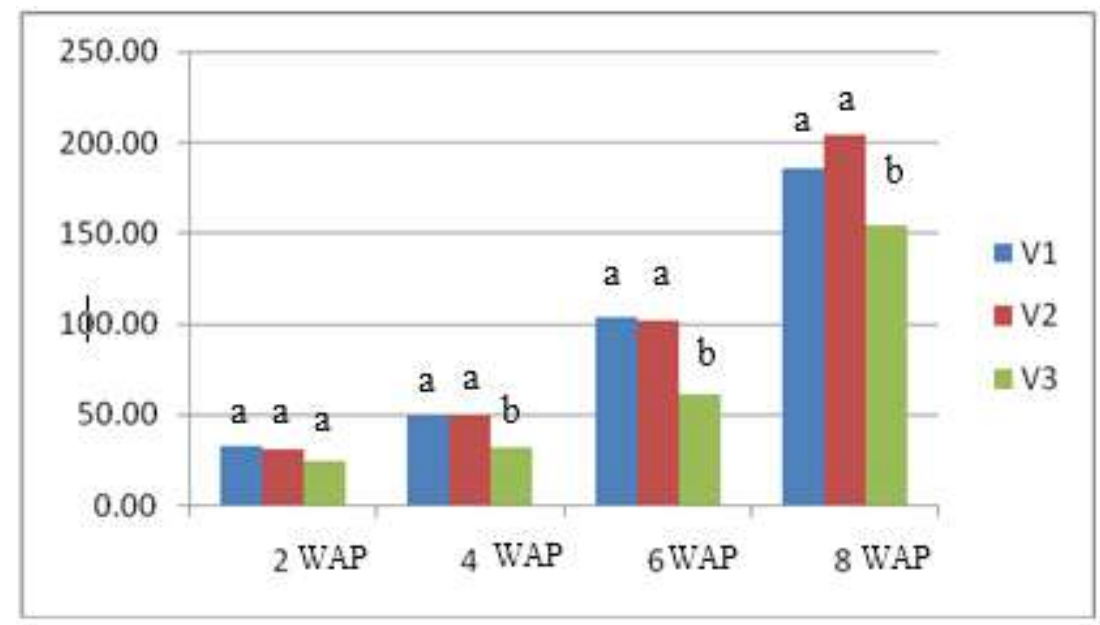

Figure 1. Effect of Varieties on Plant Wight of Tomato At Various Growth Stages

From Figure 1 it can be seen that V2 (Variety Permata) gives the highest yield of plant height compared with V1 (Variety Niki F1) and V3 (Variety Mentari).

The effect of varieties and techniques of use water to the number of leaves of tomato plants at the age of 2 to 8 MST are presented in Figure 2.

Figure 2 shows that the best results at age 2 WAP obtained at treatment V1 (Variety Niki F1), the number of plant leaves 75.6 strands followed by V2 (Variety Gems) with a number of plant leaf blade 75.2 and the lowest number of plant leaves V3 (Mentari varieties) is 49.2 strands.

Figure 2 also shows the best results at the age of 4 WAP obtained at treatment V1 (Variety Niki F1) by the number of leaves 96.8 strands, followed by V2 (Variety Permata) by the number of leaves and number of strands 83.4 lowest plant V3 (varieties Mentari) ie 63.6 strands.

Figure 2 also shows the best results at the age of 6 WAP obtained at treatment V1 (Variety Niki F1) with the amount of 133.20 leaf strands, followed by V2 (Variety Permata) by the number of leaves and number of strands 122.00 Lowest plant V3 (varieties Mentari) ie 94.00 strands.

Figure 2 also shows the best results at the age of 8 WAP obtained at treatment V1 (Variety Niki F1) with the amount of 267.80 leaf strands, followed by V2 (Variety Permata) 
by the number of leaves and number of strands 262.80 Lowest plant V3 (varieties Mentari) ie 227.80 strands.

From Figure 2 it can be seen that the best results in the treatment V1 (Variety Niki F1), followed by V2 (Variety Permata) and the lowest number of plants V3 (Mentari varieties).

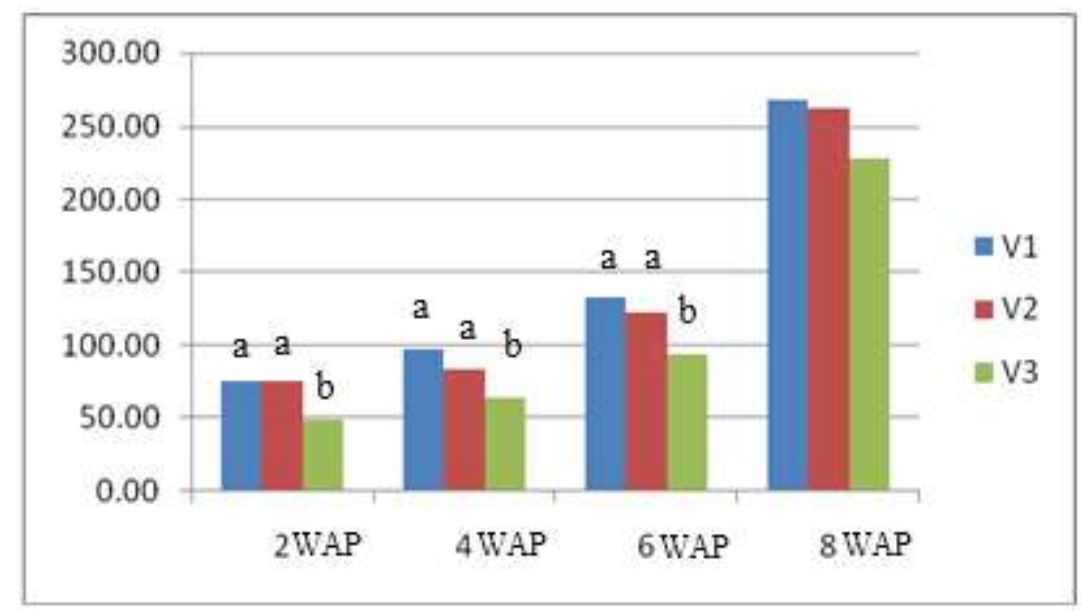

Figure 2. Effect of Varieties on The Amount of Leaf Number at Various Growth Stages

The effect of varieties and techniques of use water to total chlorophyll tomato plants at the age of 2 to $8 \mathrm{WAP}$ are presented in Figure 3.

Figure 3 shows that the best results at age 2 WAP obtained at treatment V1 (Variety Niki F1), the amount of chlorophyll 101.82 followed by V3 (Mentari varieties) with the amount of chlorophyll 101.2 and the lowest amount of chlorophyll V2 (Variety Permata) at 96, 62.

Figure 3 also shows the best results at the age of 4 WAP obtained at treatment V2 (Variety Permata) with the amount of chlorophyll 120.76, followed by V1 (Variety Niki F1) with the amount of chlorophyll 120,22 and lowest amount of plant chlorophyll V3 (Mentari varieties) is 108,8 .

Figure 3 also shows the best results at the age of 6 WAP obtained at treatment V1 (Variety Niki F1) with the amount of chlorophyll 132.64, followed by V2 (Variety Permata) with the amount of chlorophyll 129.98 and the lowest amount of plant chlorophyll V3 (Mentari varieties) is 119.42

Figure 3 also shows the best results at the age of 8 WAP obtained at treatment V1 (Variety Niki F1) with the amount of chlorophyll 150.08 followed by V2 (Variety Permata) with the amount of chlorophyll 148.14 and the lowest amount of plant chlorophyll V3 (Mentari varieties) is 138,50 . More specifically influence on the amount of chlorophyll varieties of tomato plants at the age of 2-8 MST is presented in Figure 3.

From Figure 3 it can be seen on the amount of chlorophyll in most tomato plants in treatment V1 (Variety Niki F1) with the amount of chlorophyll 150.08 followed by V2 (Variety Permata) with the amount of chlorophyll 148.14 and the lowest amount of plant chlorophyll V3 (varieties Mentari) ie 138.50. 


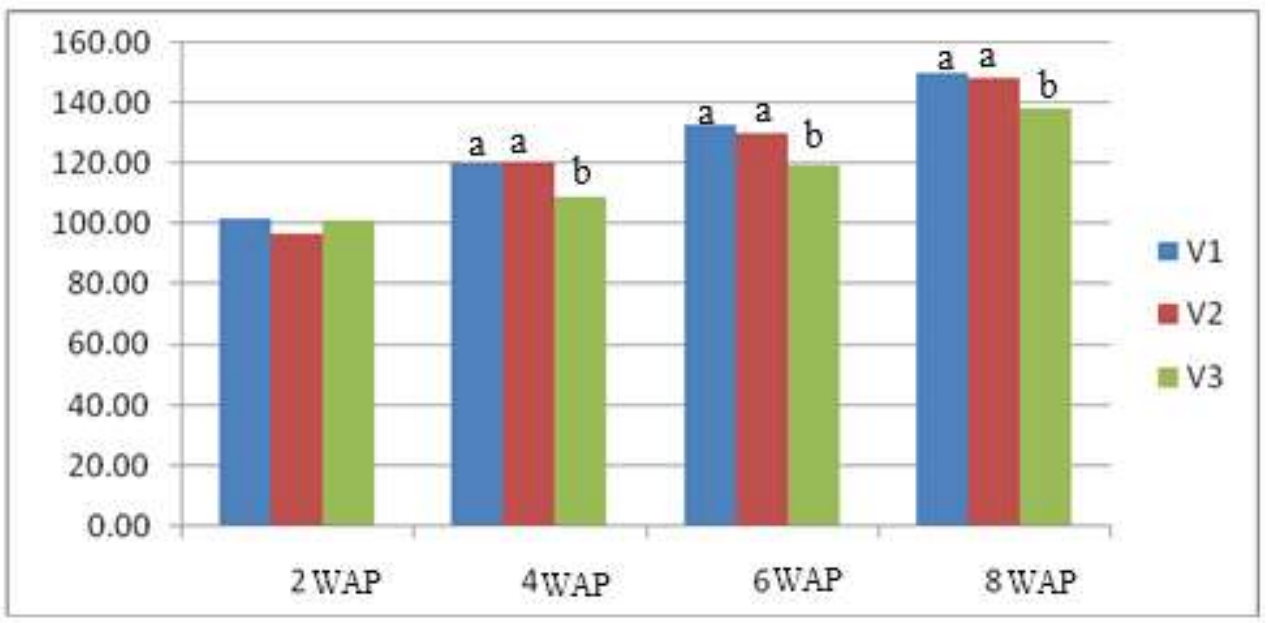

Figure 3. Effect of Varieties on the Amount of Chrolophyl Tomato at Age 2-8 WAP

The effect of varieties and techniques of use water to wet and dry weight of the plant canopy, wet weight and dry weight of root plant and leaf area index (LAI) tomato plants at the age of 4 WAP is presented in Figure 4,5, and 6.

Figure 4 shows that the best canopy wet weight at the age of $4 \mathrm{WAP}$ obtained at treatment V1 (Variety Niki F1), with a weight of $58.06 \mathrm{~g}$ followed by V2 (Variety Permata) with a weight of $43.45 \mathrm{~g}$ and the lowest in the V3 (Mentari varieties) is 26,61g, while the treatment techniques of use water and interaction varieties and techniques of use water no significant effect on the canopy of the plant wet weight at the age of 4 WAP.

Figure 4 shows that the best dry weight root at the age of 4 WAP obtained at treatment V1 (Variety Niki F1), with a weight of $7.57 \mathrm{~g}$ followed by V2 (Variety Permata) with a weight of $5.6 \mathrm{~g}$ and the lowest in the V3 (Mentari varieties) is $3,43 \mathrm{~g}$, while the treatment techniques of use water and interaction varieties and techniques of use water no significant effect on the dry weight of the plant parts above the age of 4 WAP.

Figure 4 shows that the best LAI at age 4 WAP obtained at treatment V2 (Variety Permata) of 122.76 followed by V1 (Variety Niki F1) of 120.22, and the lowest in the V3 (Mentari varieties) that is equal to 108.88 .

Figure 5 shows that the best wet weight root at the age of 4 WAP obtained in treatment P3 (Partial rootzone drying at intervals of once a day added of water once) weighing $4.34 \mathrm{~g}$, and the lowest in treatment P2 (Deficit Irigation = a half field capacity) is weighing 1, $72 \mathrm{~g}$.

Figure 6 also shows that the best dry weight root at the age of 4 WAP obtained in treatment P3 (Partial rootzone drying at intervals of once a day added of water once) weighing $3.14 \mathrm{~g}$, and the lowest in treatment P2 (Deficit Irigation = a half field capacity) is weighing 1 , $26 \mathrm{~g}$.

Figure 6 also shows that the combined treatment of varieties and techniques of use water the best on the wet weight of the roots obtained at treatment V3P3 (Variety Mentari and Partial rootzone drying technique with an interval of once a day added of water once) weighing 5.15 $\mathrm{g}$, while the lowest result obtained in the combined treatment V3P2 (Variety Mentari and Deficit Irigation $=$ a half field capacity)) weighing $0.85 \mathrm{~g}$. 


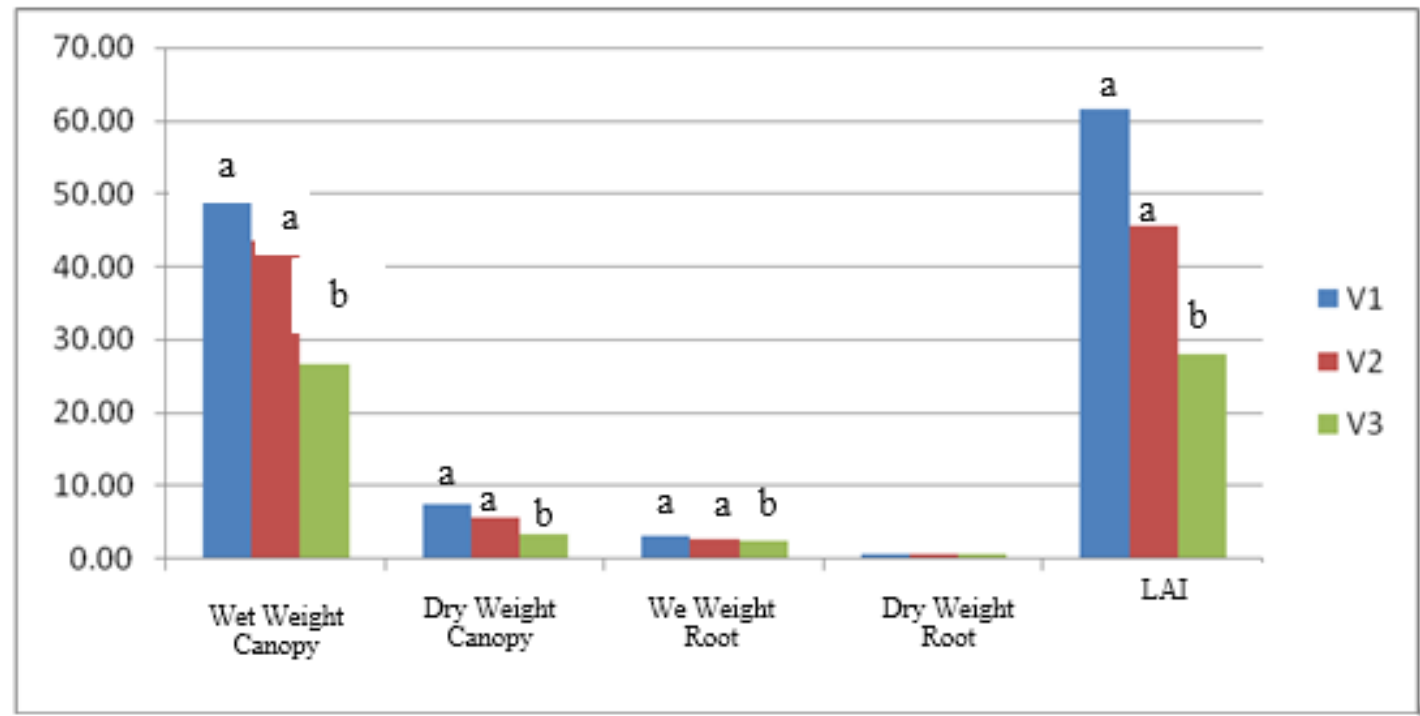

Figure 4. Effect of Varieties And Techniques of Use Water To Wet Weight and Shoot Dry Weight, Fresh Weight And Dry Weight of Root, Leaf Area Index of Tomato Plants at The Age Of 4 WAP

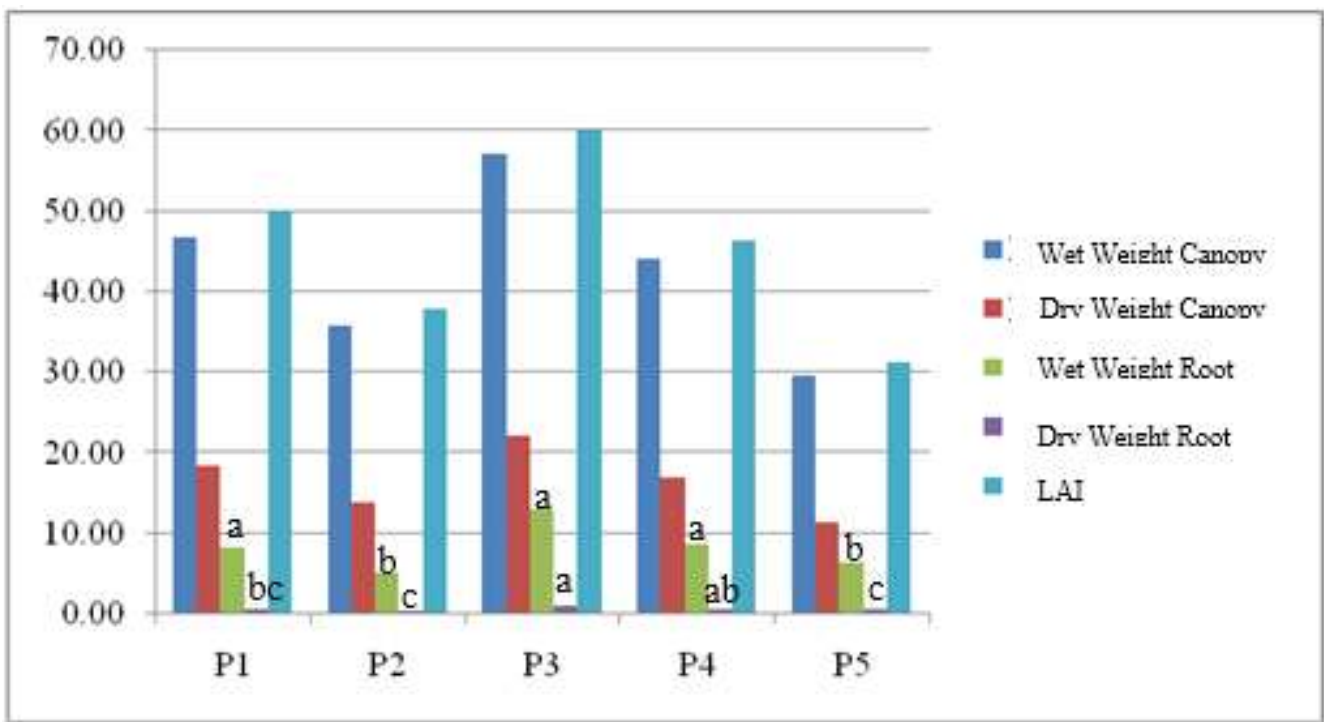

Figure 5. Effect Techniques of UseWater for Wet Weight Canopy, Dry Weight Canopy, Wet Weight Root, Dry Weight Root and LAI at age 4 WAP 


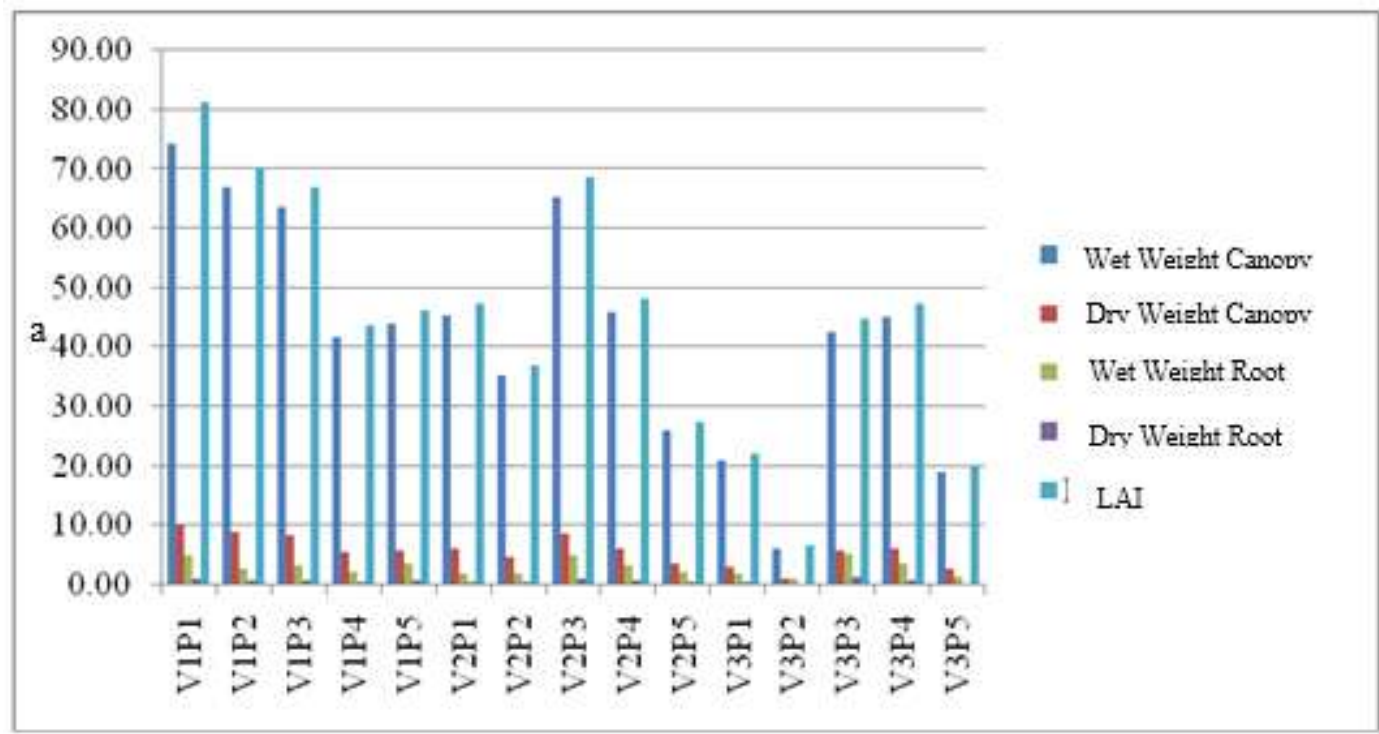

Figure 6. effect of varieties and techniques of use water to wet weight and shoot dry weight, fresh weight and dry weight of root, leaf area index of tomato plants at the age of 4 WAP

From Figure 7 shows that the highest TSS at harvest obtained at treatment V3 (Mentari varieties) as many as 24.56 brix, followed by V2 (Variety Permata) of 23.08 and the lowest brix V1 (Variety Niki F1) at 22.60 brix .

Figure 8 shows that the highest amount of fruit at harvest time obtained in treatment P3 (Partial rootzone drying at intervals of once a day added of water once) 24 fruitss, and the lowest in treatment P2 (Deficit Irigation equal a half field capacity) is weighing 6 fruits.

Figure 8 shows that the weight of the heaviest fruit at harvest time obtained in treatment P1 (Full Irigation) weighing $321.19 \mathrm{~g}$, and the lowest in treatment P2 (Deficit Irigation equal a half field capacity) is weighing $42.13 \mathrm{~g}$.

Figure 8 shows that the highest TSS at harvest obtained at treatment P5 (a half field capacity at intervals of three days once the water added) of 26.06 brix, and the lowest in treatment P2 (Deficit Irigation equal a half field capacity) is as much as 21.10 brix .

Figure 9 shows that the combined treatment of varieties and techniques of the use water on the variable amount of flowers obtained on treatment V2P3 (Variety Permata and Partial rootzone drying at intervals of once a day added of water once) by 44 while the number of the lowest flowers rate in the combined treatment obtained V1P5 (Variety Niki F1 and a half field capacity at intervals of three days once the water added) as much as 17 flowers.

Figure 9 shows that the combined treatment of varieties and techniques of the use water on a variable amount of fruits obtained at treatment V1P5 (Variety Niki F1 and a half field capacity at intervals of three days once the water added) of 26.70, while the lowest number of fruits obtained in the combined treatment V1P2 (Variety Niki F1 and Deficit Irigation equal a half field capacity) as much as 17 flowers.

Figure 9 shows that the combined treatment of varieties and techniques of the use water on fruit weight variables obtained at treatment V3P1 (Variety Mentari and Full Irigation) weighing $471.41 \mathrm{~g}$ while the lowest fruit weight obtained in the combination treatment V2P1 (Variety Permata and Full Irigation) weighing 17, $27 \mathrm{~g}$ 


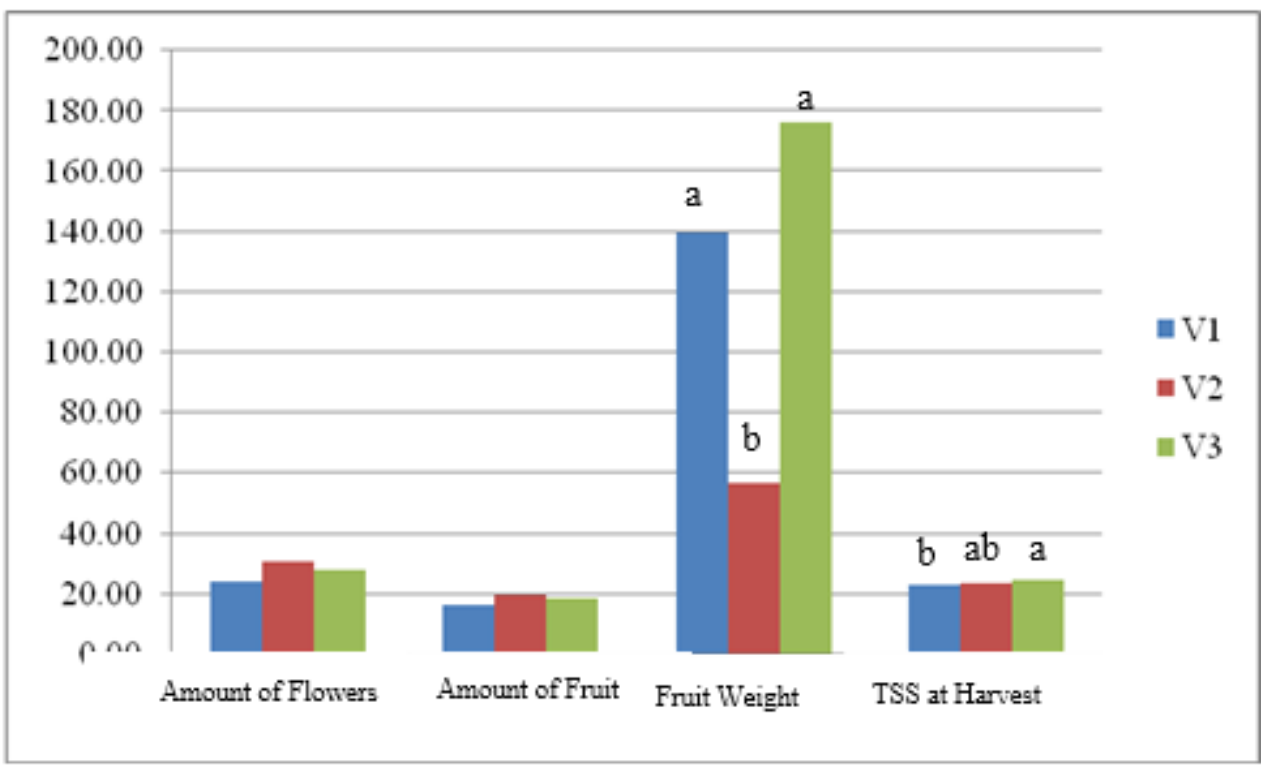

Figure 7. Effect of varieties on the amount of flowers, fruit number, fruit weight and TSS at Harvest

From Figure 7 it can be seen that V3 (Mentari varieties) gives the highest amount of the observations Fruit weight and TSS at harvest), followed by treatment V1 (Variety Niki F1) and the lowest in the V2 (Variety Permata).

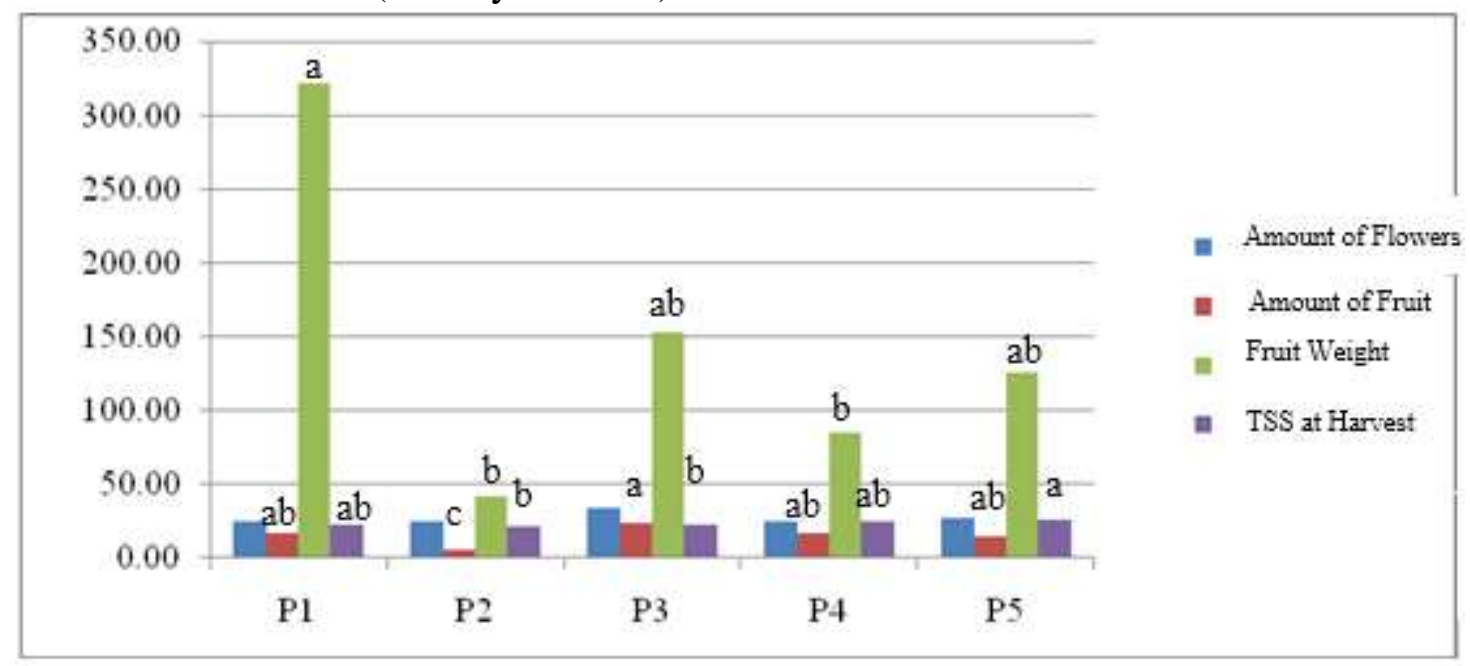

Figure 8. Techniques of the use water on the vamount of flowers, the amount of fruit, Weight fruit and TSS, at harvest

From Figure 8 shows that the highest number of fruit at harvest time obtained in treatment P3 (Partial rootzone drying at intervals of once a day added of water once ) and the lowest in treatment P2 (Deficit Irigation equal a half capacity).

From Figure 8 shows that the weight of the heaviest fruit at harvest time obtained in treatment P1 (Full Irigation) and the lowest in treatment P2 (Deficit Irigation equal a half capacity). 
From Figure 8 also shows that the highest TSS at harvest obtained at treatment P5 (a half field capacity at intervals of three days once the water added) and the lowest in treatment P2 (Deficit Irigation equal a half capacity).

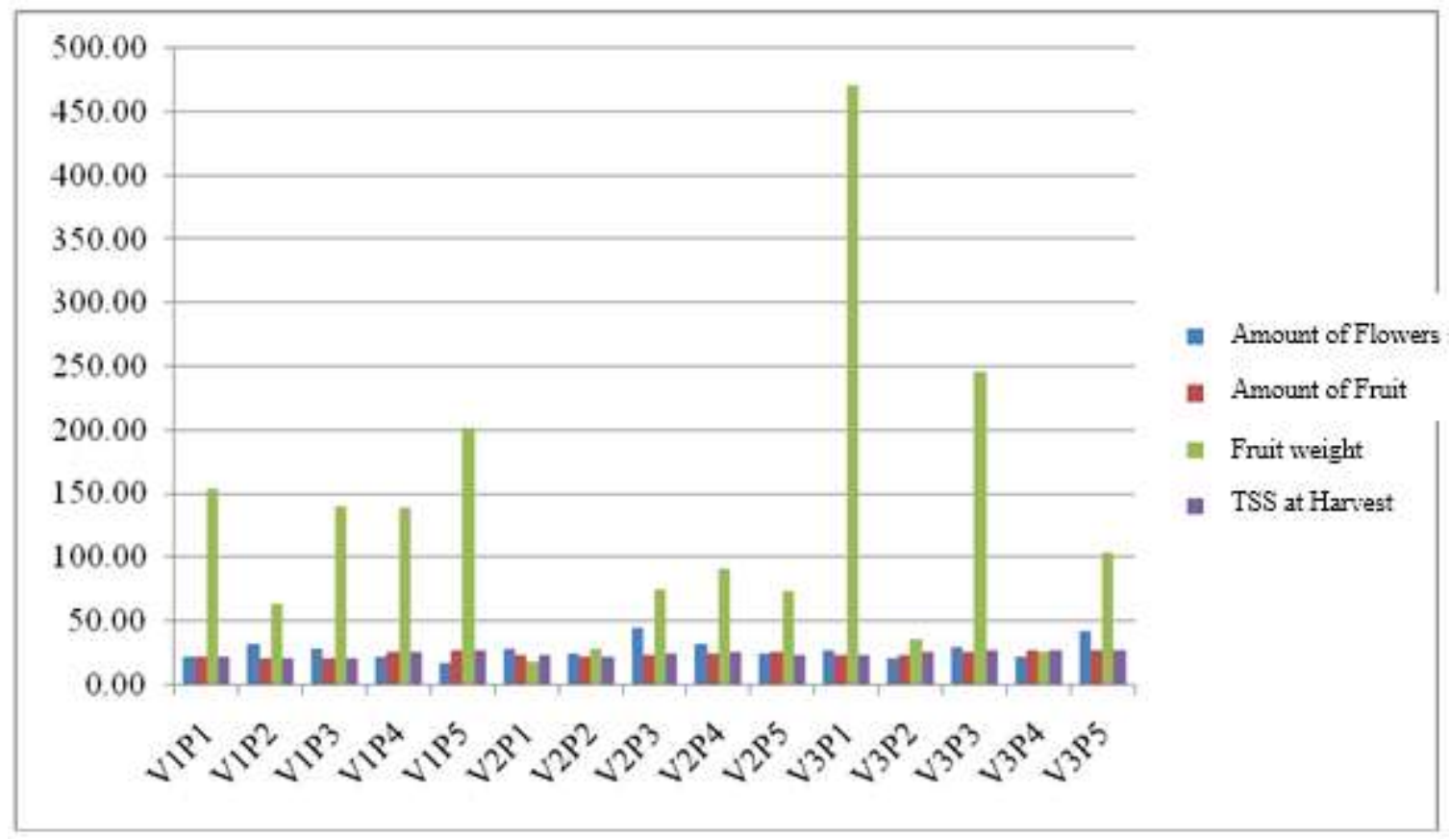

Figure 9. Effect of Varieties, Techniques of The Use Water and Combination of Both on The amount of Flowers, The Amount of Fruit, Weight Fruit and TSS at Harvest

Figure 9 shows that the combined treatment of varieties and techniques of the use water on the variable amount of flowers obtained on treatment V2P3 (Variety Permata and Partial rootzone drying at intervals of once a day added of water once) while the number of the lowest flowers acquired in the combination treatment V1P5 (Variety Niki F1 and a half field capacity at intervals of three days once the water added).

From Figure 9 also shows that the combined treatment of varieties and techniques of the use water on a variable amount of fruits obtained at treatment V1P5 (Variety Niki F1 and Partial a half field capacity at intervals of three days once the water addeda half field capacity at intervals of three days once the water added) while the lowest number of fruits obtained in the combination treatment V1P2 (Variety Niki F1 and Deficit Irigation equal a half capacity). From Figure 9 also shows that the combined treatment of varieties and techniques of the use water on fruit weight variables obtained at treatment V3P1 (Variety Mentari and Full Irigation) while the lowest fruit weight obtained in the combination treatment V2P1 (Variety Permata and Full Irigation).

\subsection{Discussion}

\section{a. Effect of Varieties on the Growth, Yield and Quality of Tomatoes}

Varieties very significant effect on plant height, amount of leaves, amount of chlorophyll, significantly affect the canopy wet weight, root dry weight plant, fruit weight and total soluble sugar (TSS) and the effect was not significant on to the wet weight of the root, the amount flower and fruit amount. 
Treatment of different varieties as a result of the PRD method applied is in a state of poor water turned out to give effect to the vegetative and generative phase of tomato plants. According Ahmadi, et al., (2010), there are two factors that affect the production ie external factors and factor in. External factors are influenced by the environment while influenced by genetic factors. Furthermore stating if there is water or water deficit stress during vegetative growth, then growth and inhibited cell growth and the leaves become smaller so little that can be translocatedphotosynthatekebuah, consequently becomes smaller fruit size. If the water deficit occurs after leaf expansion, especially after filling fruit or seeds there will be competition between the leaves and seeds in using photosynthate that formed relatively little fruit and cause small fruit size, so it will automatically affect the weight and quality of the fruit produced. Furthermore, according Davies., et al ,. (2000), cultivar improvement needs to be done in order to obtain varieties that are resistant to environmental stress factors such as wilt disease resistance, resistance to heat and resistance to rain, resistance to environmental change or unfavorable growing environmental stress.

\section{b. Effect Giving of Water Technique on Growth, Yield and Quality of Tomatoes}

Techniques of use water significantly affect wet weight root and dry weight root, amount of fruits, fruit weight and total soluble sugar (TSS) and no significant effect on plant height, amount of leaves, amount of chlorophyll and leaf area index, amount of flowers. The difference in techniques of use water deranging from giving a field capacity which is rubbed surface of the soil to the water supply half field capacity provided through the ground and through the pipe directly to the plant roots with the PRD method turned out to affect the phase of vegetative and generative phase.

It was shows that the added of water on tomato plants have efficient and qualified for production, although at half field capacity. According to (Zhang, 2003), productivity (water productivity) associated with efisieni of water applied to crops.

According Yactayo, et al., (2013), crop water shortage can result in death, otherwise the excess water can cause damage to plant roots, due to lack of air in the waterlogged soil, lack of water in plants occurs due to the availability of water in the media is not sufficient and excessive transpiration or a combination of both factors. In the field although in sufficient water available in the soil, plants can suffer stress (lack of water). This occurs if the absorption rate can not compensate for water loss through transpiration. Setting stomatal closure and reduction of leaf area will increase abscisic acid (ABA). This is the primary physiological responses to reduce the transpiration of plants with the PRD method (giving water to a part of the plant root zone) and increase water productivity. PRD technique increases the productivity of water in various types of plants. Sadras (2009) states that the use of the PRD increase water productivity by $82 \%$ compared with the provision of a field capacity with no significant reduction of the results.

\section{c. Effect of Combination of Varieties and Technical Giving of Water on the Growth, Yield and Quality of Tomatoes}

The combination of several varieties and techniques giving of water very significant effect on wet weight root and the amount of flowers, significantly affect the amount of fruit, fruit weight each of the polybag tomatoes but not significant effect on plant height, amount of leaves, amount of chlorophyll, the wet and dry weight of the canopy, dry weight root, and amount flowers, amount fruit number. And total soluble sugar (TSS) 
Based on the results of the analysis showed that the combination treatment of varieties and techniques of use water that tested positive response both to the phase of vegetative and generative phase, although there are different techniques of giving of water ranging from giving a field capacity which is rubbed surface of the soil to the water supply half field capacity provided through the ground and through the pipe directly to the plant roots with the PRD method.

It was shows out that the added of water on tomatoess have efficient and qualified for production, although at half field capacity. According to (El-Sadek Alaa. 2013).), water productivity associated with efisieni of water applied to crops. Thus during plant growth does not occur so that the water deficit in the process of growth and development during vegetative growth is not inhibited and the leaves of many results that can be translocated photosynthate to fruit, so the fruit is formed many and large fruit size, so it will automatically affect the weight and quality of the fruit resulting from

\section{Conclusions}

1. Varieties very significant effect on plant height ages 2 and 4 Week After Planted (WAP), significantly affected the number of leaves 2 and 4 WAP, the amount of chlorophyll age 4 WAP, wet weight and dry weight of the canopy plant age 4 WAP, and the effect is not significantly affected to the amount of chlorophyll at the age of 2 WAP, wet weight of root and dry weight of roots and the amount of flowers at the age of 4 WAP. significantly affected on wet weight of canopy and dry weight of canopy, weight fruits and Total Soluble Solution (TSS) at respectively at harvest. The best results obtained at V1 treatments (varieties Niki F1), followed by V2 (Permata varieties) and the lowest V3 (Mentari varieties).

2. Techniques of treatment water is only influence significantly affect the wet weight and dry weight of roots at the age of $4 \mathrm{WAP}$, the amount of fruits, weight of fruits and Total Soluble Solution (TSS) respectively at harvest and no significant effect on the observations of other variables. The best results obtained on treatment P3 (Partial rootzone drying at intervals of 1 day once the water supply), and lowest in treatment P2 (Deficit Irigation equal a half field capacity).

3. Combination treatment of varieties and techniques of water showed very significant effect on wet weight root and the amount of flowers at harvest, significant effect on the amount of fruits, weight of fruits and Total Soluble Solution (TSS) respectively at harvest and showed no significant on all variables other observations, the best results obtained in the combination treatment V3P3 (Variety of Mentari and Partial rootzone drying technique with interval of 1 day once the water supply), while the lowest yield is obtained in the combination treatment V1P5 (Variety Niki and Partial rootzone drying at intervals of 3 day once the water supply),

\section{Acknowledgements}

On this auspicious occasion we express our deepest gratitude to the Honorable: The Director General of Higher Education that has funded this research through a Strategic Competitive Grant research program nationally, and Mr. Rector and Chairman of the Univa Lemlit given opportunities and facilities. 


\section{References}

Ahmadi, S.H., Andersen, M.N., Plauborg, F., Poulsen, R.T., Jensen, C.R., Sepaskhah, A.R., Hansen, S., 2010. effects of irrigation strategies and soils on field grown potatoes: Yield and water productivity. Agri. Water Management.

DOI 10.1`016/j.agwat.2010.07.007.

Davies, W.J., M.A. Bacon, D.S. Thompson, W. Sobeigh, L.G. Rodriguez, 2000. Regulation of leaf and fruit growth in plants in drying soil: exploitation of the plant's chemical signalling system and hydraulic architecture to increase the efficiency of water use in agriculture. J. Exp. Bot., 51, 1617-1626.

El-Sadek Alaa. 2013. Water use optimisation based on the concept of Partial Rootzone Drying. Ain Shams Engineering Journal. P.O. Box 26671, Manama, Bahrain

Loveys, B.R., P.R. Dry, M. Stoll, M.G. McCarthy, 2000. Using plant physiology to improve the water use efficiency of horticultural crops. Acta Hort., 537, 187-199.

Sadras, V.O., 2009. Does partial root-zone drying improve irrigation water productivity in the field? A metaanalysis. Irrigation Science, 27: 183-190

Setiobudi, D., dan Fagi, A.M., 2008 Pengelolaan Air Padi Sawah Irigasi: Antisipasi Kelangkaan Air dalam Padi Inovasi Teknologi dan Ketahanan Pangan Balai Besar penelitian Tanaman Padi. Balitbang Pertanian. p 250-279.

Steduto P., Hsiao T.C., Fereres E., and Raes D., 2009. Water scarcity and the FAO model AQUACROP, Interdrought III Abstract, L 2.01.

Yactayo Wendy, David A. Ramírez*, Raymundo Gutiérrez, Víctor Mares,Adolfo Posadas, Roberto Quiroz. 2013. .Effect of partial root-zone drying irrigation timing on potato tuber yield and water use efficiency. Agricultural Water Management. j ourna 1 ho me page: www.elsevier.com/locate/agwat. International Potato Center (CIP), Apartado 1558, Lima 12, Peru

Zhang, H., 2003. Improving water productivity through deficit irrigation: Examples from Syria, the north China Plain and Oregon, USA. In: Water Productivity in Agriculture: Limits and Opportunities for Improvement (Kijne, J.W., Barker, R., and Molden, D. eds). CABI publishing, 332p. 